\title{
Damages Granted by the State and their Relation to State Aid Law
}

\author{
Michiel Tjepkema*
}

This article deals with compensations granted by government and their relation to State aid law. It focuses on compensations that can be dealt with under Article 107(2)(b) and 107(3)(c) and which, as a rule, are granted after damage was caused by acts outside of government control, such as floods, earthquakes, and industrial accidents. The article discusses several criteria used by the courts to test compensations applicable under the State aid rules. Second, the article discusses situations where government can be held liable in court, since unlawful or even lawful actions of public authorities caused the damage. In those cases, the Asteris case law rules the compatibility of compensations with State aid rules. According to this case law, legally obliged compensations are 'fundamentally different' in nature from State aid. This case law is discussed, and a few general rules distilled from it. By discussing examples from the European Commission practice, recent case law from the GC (the ThyssenKrupp case) and national compensation regimes, I will point out that the line between State aid and compensation is not always easy to define. The risk of granting unlawful State aid is certainly present in cases of liability in the absence of fault, which liability is dependent on criteria that are surrounded by vagueness, such as the 'normal business risk' of an undertaking.

\section{Introduction}

The subject of this article is the relation between EU State aid law and damages paid by national authorities. ${ }^{1}$ This subject has not been given much attention in State aid literature. This does not mean that this subject has no practical and theoretical importance. In fact, the Commission is frequently confronted with government compensations and has to test their compatibility with the State aid rules. One example, which will be discussed later on, is the large sums of money which are spent on compensating farmers who somehow suffer from (legitimate) measures combating contagious diseases. Member States granted damages in many other situations as well, however. Sometimes, these payments find their ground in a legal obligation, such as liability in tort, infringement to the right to property (expropriations), or default. On a regular basis, governments spend large sums of money in situations where they have not acted unlawfully. ${ }^{2}$ Even then, in the absence of fault, a legal obligation to compensate can exist, namely when government has breached the principle of égalité devant les charges publiques (equality before the public burdens). This principle states that the disproportionate adverse consequences of a lawful action of public authorities should not burden a rela- tively small group of citizens, but should be borne by society as a whole, since the harmful act was in the general interest. ${ }^{3}$ Further, governments regularly pay large sums of money by their own will, even where there is no legal obligation to do so. Such ex gratia payments can be a part of government policy and are granted when government does not want to admit it can be held liable. In England, for example, ex gratia

* Dr. M.K. G. Tjepkema is Assistant Professor at the Department of Constitutional and Administrative Law at Leiden University. He would like to thank Prof. W. den Ouden and Dr. P. C. Adriaanse for their valuable comment on an earlier draft.

1 This article therefore does not deal with the question of competitors claiming damages in cases of unlawfully granted State aid. See on this subject Honoré and Eram Jensen, Damages in State Aid Cases, EStAL, 2011, 2, p. 265 et seq.

2 In the Netherlands for example, public authorities spend as much or even more money on liability without fault than on tort based liability. In the case of airport Schiphol for example, government spent up to 30 million to residents whose houses have been depreciated after lawful measures relating to the functioning of the airport (e.g. decisions involving noise restrictions or spatial acts)

3 In France, this type of liability is recognized for almost all lawful government acts: not only decisions, but also non-legal acts (road repair for example), and laws adopted by parliament. Other legal systems also recognize the equality principle (e.g. Germany, Belgium, the Netherlands, Luxembourg, Spain and Portugal). 
payments are a large part of the compensations the government pays to individuals. ${ }^{4}$

When the granting of damages is strictly based on the general legal principles, a State aid problem will not arise, as I will explain in part III. Liability based on fault, in particular, does not mean that an 'advantage' is given to an undertaking; liability ensures that a damaged party is given what it is entitled to. Since the legal principles governing liability apply to every undertaking in the same way, it is also hard to claim that the application of a legal principle in a concrete case can be considered as 'selective'. Yet, public authorities sometimes make special 'arrangements' for the granting of damages. These are, as a rule, laid down in a regulation which applies to a special group of undertakings. At least in those cases, a State aid problem can indeed arise. In those cases, it turns out

4 For a recent discussion, see Harlow, Rationalizing administrative compensation, Public Law, 2010, p. 321-339.

5 This is also the case when the compensation is not provided directly by the State, but goes first to an insurance company, which uses the money to compensate the companies concerned: Commission Decision of 15 October 2003, C(2003) 3551fin. Even the proceeds of para-fiscal levies, which ask an undertaking to deposit money in a fund, can be qualified as 'State resources' (Case C-345/02, Pearle [2004] ECR I-7139).

6 For example, companies normally have to bear the costs of having to vaccinate animals themselves. Likewise, they have to bear the damage caused by bad weather conditions. When government intervenes and decides to carry the burdens that a company normally has to carry itself, this is clearly advantageous. The exact extent of compensation is not decisive aid to be regarded as beneficial. Both when the measure is designed for all damage (Commission Decision of 6 December 2002 concerning a one-off compensation of $100 \%$ of the losses of beeches caused by bark beetles, C(2002) 4849) or only a portion thereof (Commission Decision of 4 July 2003, concerning a compensation of $15 \%$ of the remediation costs in order to sanitize a former gasworks site, C(2003) 2374), can it be 'beneficial'.

7 The exact size of the group will not be the point of most concern: the selectiveness criterion was met in cases where a relatively limited group profited from a contribution (only poultry farmers, for example, Commission Decision of 4 August 2005, C(2005) $3113)$, but was also met in cases where large groups of companies (all agricultural companies, for example; see Commission Decision of 15 October 2003 concerning a subsidy for new agricultural assurances, C(2003) 3551fin). See for an application of the selectiveness test also the decision in the Thyssen Kruppcase, para. 100 (to be discussed in part. IV).

8 A recent example in Dutch law concerns the plans of government to prohibit the breeding of minks for their pelts. One reason for not compensating the breeders financially (but offering them a large transition period instead) is the fear of unfairly favouring Dutch breeders over other European breeders. See Kamerstukken II 2007/08, 30 826, nr. 6, p. 3-4.

9 The Guidance on State aid law and damage compensation (Handreiking nadeelcompensatie en staatssteun) published in 2007 by the Ministry of Economic Affairs. that government payments easily meet the State aid criteria, as they are provided by State resources. ${ }^{5}$ Furthermore, the Commission tends to readily assume that compensation provides a company with an advantage: it suffices that the contribution provides them with an advantage that they would normally not have had and would normally bear themselves. ${ }^{6}$ The condition of selectivity then normally does not pose a problem either: when a contribution is granted to a group of companies with a particular characteristic, the Commission, as a rule, will conclude that the advantage is selective, since this group then takes a special position compared with other comparable companies. ${ }^{7}$ Lastly, when the undertaking carries out its activities in an international market, it will be assumed that the compensation might affect the trade between Member States, and, therefore, it might be incompatible with the common market.

In light of the similarities between compensations and State aid, there are many instances where the tension between the payment of damages and State aid law is tangible. ${ }^{8}$ This has prompted the Dutch Ministry of Economic Affairs to write a manual that civil servants can use when taking decisions on compensations and when they are in doubt of granting State aid. ${ }^{9}$ The fact is that even when public authorities claim they are, from a national law perspective, legally obliged to grant compensation, there might be the risk of de facto granting unlawful State aid from an EU law perspective. This article hopes to shed light on this subject, which balances on the fine line between law and policy. Part II deals with the question of what the TFEU currently says on government compensations and the conditions that must be fulfilled to be compatible with State aid law. This concerns mainly cases where the damage is not (directly) caused by government action but has an exterior cause; sometimes, these payments are held compatible with the State aid rules since one of the exceptions of either Art. 107 (2)(b) or 107 (3)(c) apply. It is important to distinguish these cases from the situations dealt with in Part III and IV, where the damage is caused by (unlawful or even lawful) government action. The framework the Commission uses to test the compensations' compatibility with State aid law differs in both cases. The criteria used by the Commission and the Union Courts to test measures in both cases are discussed in Part III. Finally, Part IV deals with the question of whether mandatory compensations can come within the borders of the State aid rules. Two criteria are discussed that can 
function as indicators of the 'instrumental' use of compensation mechanisms.

\section{The Regulations on the Compensation of Damages Enshrined in Article 107(2)(b) ...}

First of all, it should be noted that where the aid does not surpass the amounts set in the de minimis' regulation, there is no risk of granting State aid. This means that aid not exceeding a ceiling of $€ 200$ ooo over any period of three years does not affect trade between Member States and does not distort or threaten to distort competition and therefore does not fall under the scope of Art. 107 (1) TFEU. The amounts which are exempted are much lower in some fields however, such as the agriculture and fisheries sectors. ${ }^{10}$

When a compensation surpasses the de minimis threshold, it might still be compatible with State aid rules, namely when one of the exceptions of Article 107 applies. The Treaty offers a special set of rules for compensations that serve to compensate for the damage caused by natural disasters or exceptional occurrences (Article $107(2)(b)$ ) and for the aid provided to facilitate the development of certain economic activities or of certain economic areas (Article 107(3)(c)). ${ }^{11}$ In this paragraph, I want to show the criteria the Commission, the ECJ, and the GC use to test government compensations against their compatibility with the internal market under these articles. It should be noted that the Commission has plans to exempt certain categories of aid from prior notification to the Commission, such as aid for compensating damages caused by natural disasters and aid to compensate the damage caused by adverse weather conditions in fisheries. One of the reasons to allow for block exemptions in these fields is that the Commission has acquired significant practical experience in recent years with regard to these categories of State aid. ${ }^{12}$ The compatibility criteria used with regard to natural disasters and exceptional occurrences will now be discussed.

\section{Compensations in Relation to Natural Disasters and Exceptional Occurrences}

The Commission and the ECJ have repeatedly stressed that Article 107(2)(b) TFEU should be inter- preted restrictively. ${ }^{13}$ So far, the Commission has accepted that earthquakes, avalanches, landslides, and floods may constitute natural disasters. As the Treaty does not define those occurrences that might qualify as 'exceptional', the Commission assesses the applicability of this provision on a case-by-case basis. ${ }^{14}$ The Commission has stated, however, that the exceptional occurrence, because of its nature and consequences, must constitute a clear break with respect to the usual course of business of the companies in question; the occurrence (and its consequences) should not belong to the normal operation of the market. ${ }^{15}$

So far, the Commission has accepted the following exceptional occurrences: war, internal disturbances or strikes, and with certain reservations and depending on their extent, major nuclear or industrial accidents and fires that result in widespread loss. ${ }^{16}$ As to the nature of the occurrence, the Commission has stated that it should be unpredictable and thus unforeseeable. $^{17}$ The rationale is that undertakings can take precautionary measures against occurrences that are foreseeable to limit their damage. For example, a strike on Italian highways was not quali-

10 See for details: Commission regulation (EC) No 1860/2004 on the application of Articles 87 and 88 of the EC Treaty to de minimis aid in the agriculture and fisheries sectors, OJ $2004 \mathrm{~L} \mathrm{325/4.}$

11 On the subject of these exemptions, see also: L. Hancher, T. Ottervanger \& P.J. Slot, EU State Aids (Sweet \& Maxwell 2012), p. 142-143 and 158-160.

12 MEMO/12/936, 5 December 2012.

13 Commission Decision of 7 May 2004, OJ 2005 L 110/48-55 (Spanish olive producers) and Commission Decision of 20 September 2000, OJ 2001 L 35/39 (Aid after Italian natural disasters; para. 31). See also Commission Decision of 13 June 2000, OJ 2000 L 263/17 (Transport of Irish cattle). See also Case C-278/00, Greece v. Commission [2004] ECR I-3997, para. 81 and Case C-73/03 [2004] ECR n.y.r., Spain/Commission, paras. 37 et seq.

14 Community guidelines for State aid in the agriculture and forestry sector 2007 to 2013 (2006/c 319/01), para. 122.

15 Commission Decision 29 July 1999 concerning the Belgian dioxin crisis, No sub 2.1 (Belgian dioxin crisis). See also Commission Decision concerning special measures relating to a dioxin contamination in Ireland, Aid No NN 44/2009 (ex N 435/2009): '[I]n order to be able to categorise an event as an exceptional occurrence, the said event has to distinguish itself clearly from the ordinary by its character and by its effects on the affected undertakings and therefore has to lie outside of the normal functioning of the market.'

16 See also the Community guidelines for State aid in the agriculture and forestry sector 2007 to 2013 (2006/C 319/01).

17 Commission Decision of 3 April 2002, OJ 2002 L 194/37-44 (Italian olive producers; para. 36) and Commission Decision of 7 May 2004, OJ 2006 L 257/1-10 (Strikes of Sicilian road transporters, para. 54). 
fied as 'exceptional', since strikes occur regularly. ${ }^{18}$ Drought, even on a large scale, has also never been recognised as a natural disaster within the meaning of Art. 107(2)(b) TFEU. ${ }^{19}$

As to the extent of the damages, it is hard to draw a clear line, so I will limit myself to some examples. The Commission found that the bursting of a huge reservoir filled with toxic sludge in Hungary was exceptional, since this caused about ten deaths and enormous ecological and economic damage to the region. ${ }^{20}$ On the other hand, the Commission will not accept that a fire at a single processing plant covered by normal commercial insurance could be considered as an exceptional occurrence. ${ }^{21}$ Fires causing widespread losses, however, have been held compatible with the internal market when they qualified as a 'natural disaster.'. 22 By focusing on the nature and the extent of the damage, the Commission thus allows itself a flexible interpretation of the question as to whether an occurrence qualifies as a 'natural disaster' or as 'exceptional': even a common cause of damage, such as an outbreak of disease among animals, which normally does not qualify as a natural disaster or as

18 Commission Decision of 7 May 2004, OJ 2006 L 257/1-10 (Strikes of Sicilian road transporters, para. 56: 'Strikes can be a frequent event and, if there is advance notice, suitable precautions may be taken. The element of unforeseeability is therefore missing in this case.').

19 Commission Decision of 16 July 2008, OJ L 244/17 (Aid to the Villasor sugar refinery), para 63.

20 Commission Decision of 28 June 2011, C(2011) 4681 concerning the red sludge Ajka Alumina Plant, para. 27.

21 Community guidelines for State aid in the agriculture and forestry sector 2007 to 2013 (2006/C 319/01), para. 122.

22 Commission Decision of 24 February 2010 concerning aid to compensate for the damages caused by the fire to Palmitos Park, N 622/2008.

23 Commission Decision of 12 March 2002 concerning aid to cattle holding companies in Nordrhein-Westfalen, C(2002) 906fin.

24 Community guidelines for State aid in the agriculture and forestry sector 2007 to 2013 (2006/C 319/01), para. 122.

25 2006/C 319/1, paras. 120-123.

26 Case C-346 and C-529/03, Atzeni e. a.t. Regione autonoma della Sordegna [2006] ECR 1-1975, para. 79 and Judgment of 11 November 2004, Case C-73/03, Spain v. Commission [2004], n.y.r., para. 37.

27 Commission Decision of 7 May 2004, OJ L 257, p. 1-10, 2006 (Strikes Sicilian road transporters; para. 61).

28 Commission Decision of 20 October 2004 on the aid scheme implemented by Italy for firms investing in municipalities seriously affected by natural disasters in 2002 (notified under document number C(2004) 3893; paras. 45 et seq.).

29 Case C-278/00, Greece v. Commission [2004] ECR I-3997; para. 89. an exceptional occurrence, can be exceptional, namely when this leads to the total closure of the export markets for meat coming from the European Union and the general reluctance among European consumers to eat that meat. ${ }^{23}$ Furthermore, the Commission has stated that contagious diseases among animals and plants can be 'exceptional occurrences' if these diseases appear for the first time and lead to widespread losses. ${ }^{24}$

When an occurrence is dealt with under the clause of Article 107(2)(b), the Commission sometimes refers to their guidelines. In cases concerning damages, an important guideline is the Community Guidelines for State Aid in the Agriculture and Forestry Sector 2007-2013 (2006/C 319/01). ${ }^{25}$ Among other things, this guideline states the conditions under which governments can provide for contributions to farmers who suffer losses as a result of measures that aim to root out animal diseases. These guidelines offer little information about the conditions that compensations have to meet to be compatible with the internal market. A study of the decisions of the Commission offers important additional information on the relevant criteria.

\section{a. Direct causal link}

A criterion mentioned in many decisions is the causal link: there must be a direct link between the aid granted and the event that caused the damage. ${ }^{26}$ There should be a 'direct' or a 'necessary and exclusive causal link,, ${ }^{27}$ or at least a 'clear and direct link'. ${ }^{28}$ Whatever the exact words, they make clear that the Commission imposes stringent requirements on the causal link between the event that caused the damage and the State aid intended to remedy it. When the Commission is in doubt, it is up to the Member State to prove that the aid is justified. The State will then have to submit material regarding which damage was compensated and how the size of the aid and the group of recipients were determined. As to the extent of the damage, the Commission has stated that the aid granted should correspond to the damage supposedly inflicted upon the recipients. ${ }^{29}$ Therefore, the Commission had its doubts about an aiding mechanism that did not relate to the actual damage but to the volume of investments carried out during a certain period, the volume of investments in preceding years, and the existence of a taxable income. Even if the recipient might have suffered damage caused by the natural disasters at issue, it could not be excluded 
that the amount of aid would exceed the amount of damage. $^{30}$

When determining the causal link, the group of recipients receiving the aid also has to be taken into account. After all, when aid is given to undertakings that did not suffer any damage, this is a sign that the aid is not (only) compensatory in character, but also gives support to undertakings for other types of hardship. The aiding scheme should not have a very wide scope but should aim at specifically compensating those who suffered damage. This is not the case when the aiding scheme makes it possible to settle all kinds of debts incurred by agricultural cooperatives, provided they relate to social purposes, and if the scheme can be applied to very diverse situations. ${ }^{31}$

Lastly, the demand of a sufficiently direct causal link has a temporary element. Where aid is paid only several years after the occurrence of the event in question, there is a real risk that the payment of such aid will produce the same economic effects as operating aid. Therefore, in the absence of a specific justification, for example, resulting from the nature and extent of the event or the delayed or continuing nature of the damage, the Commission does not approve national aid that is submitted more than three years after the occurrence. ${ }^{32}$

\section{b. Prohibition of accumulation of different financial means covering the same damage}

A second issue relates to the risk of overcompensation. Its importance could be illustrated by the fact that the ECJ stated repeatedly that not only the relatively small size of the aid measure was decisive for its compatibility with the internal market, but other issues had to be examined, 'such as whether the aid is cumulative and whether the undertakings that receive it are operating in a sector that is particularly exposed to competition'. ${ }^{33}$

Accumulation takes place when more than one aiding measure covers the same costs or damages. ${ }^{34}$ When aid is given in relation to a natural disaster that constitutes an exceptional occurrence, accumulation might occur when the damaged undertaking also receives aid through other, already approved aiding measures ${ }^{35}$ or through social or insurance payments. ${ }^{36}$ To prevent overcompensation, these other aid measures have to be deducted from the aid. ${ }^{37}$ If the risk of accumulation arises, the Member State will have to make clear how this effect will be prevented.

\section{c. Objective and individual assessment of the damage}

The Member State has to show that the damage for which compensation is given is assessed in an objective and individual manner. As to objectiveness, the Commission is more likely to conclude that an aid measure is compatible with the internal market when independent experts have assessed the damages. ${ }^{38}$ Furthermore, damages, as a rule, should be assessed at the level of the individual undertaking and not at the macroeconomic level or on the basis of the average damage of several companies. This requirement has strong ties with the demand for a clear causal link. When the damage is not quantified at the level of each firm, but at the macroeconomic level (which is usually done for reasons of speed and/or efficiency, since an individual assessment takes time), it is harder to determine whether the aid is aimed at only

30 Commission Decision of 20 October 2004, OJ 2005 L 100/46 (Natural disasters Italy 2002; para. 48).

31 C-278/00, Greece v. Commission [2004] ECR I-3997, para. 85 See also Opinion of AG Geelhoed in the same case, para. 57.

32 Commission Decision of 1 March 2000, OJ 2002 L 159/1 (Debts of Greeks agricultural cooperatives; para. 142), Commission Decision of 25 July 1990, OJ 1991 L 86/ 23-27 (Aid scheme Mezzogiorno; sub IV) and Commission Decision of 20 September 2000, OJ 2001 L 35/39 (Natural disasters Italy 1990-1997; para. 35 e.v.)

33 Case C-278/00, Greece v. Commission [2004] ECR I-3997, para. 70; Case C-113/00, Spain v. Commission [2002] ECR I-7631, para. 30 .

34 Europese regelgeving over staatssteun. Informatiewijzer voor de decentrale overheid. : Ministerie van Binnenlandse Zaken en Koninkrijksrelaties 2004, p. 20 ('European rules on State Aid. Information brochure for municipalities and provinces'; The Hague 2004).

35 Commission Decision of 9 February 2000, SG(2000), D 101388 on aid measure N 770/99 (Belgian dioxin crisis), p. 11.

36 Community guidelines for State aid in the agriculture and forestry sector 2007 to 2013 (2006/c 319/01), para. 123. According to the Commission, the risk of accumulation is especially present in the field of agriculture, where farmers often receive aid from different sources (Commission Regulation (EC) No 1857/2006, OJ 2006 L $358 / 6)$.

37 See, for example, Commission Decision 7 May 2004, OJ 2006L 257/1-10 (Strikes of Sicilian road transporters; para. 50) and Commission Decision of 7 May 2004, OJ 2006 L 257/p. 1-10 (Agricultural companies had to declare that they would not take judicial steps against the striking road transporters in order to prevent a double compensation).

38 Commission Decision of 6 June 2002, C (2002) 1674 concerning aid measure $\mathrm{N} 217 / 2002$ in the case of the fireworks disaste Enschede. See also Commission Decision of 14 July 2004, OJ 2006 L 74/49 (Ship wreck Erika; the aid scheme contained an adequate procedure to prevent overcompensation; para. 61). 
compensating for the damage. This also applies to indirect forms of damage, such as production delays because of electricity cuts or difficulties in delivering products because of the blockage of certain transport routes. These may be compensated up to $100 \%$, but the damage should be assessed at the level of the individual firm. ${ }^{39}$ In some cases, the Commission is somewhat lenient in its approach. ${ }^{40}$

\section{d. No compensation for normal entrepreneurial risks}

When a natural disaster or an exceptional occurrence causes damage, the Commission will permit compensation aid of up to $100 \%{ }^{41}$ However, the Commission will test critically whether the damage that is compensated does not fall within the normal entrepreneurial risks of the undertaking. If this is the case, the damage should not be compensated. An example of normal entrepreneurial costs is the damage caused to farmers by animal and plant diseases. The Guidelines state that for the companies active in the processing and marketing of agricultural products, the impact of such diseases on their business must be considered a normal business risk. If such companies face economic difficulties because of the effects of animal or plant diseases, they may be supported via rescue and restructuring aid however. ${ }^{42}$

39 Commission Decision of 20 October 2004, OJ 2005 L 100/46 (Natural disasters Italy 2002, para. 46).

40 Commission Decision of 14 July 2004, OJ 2005 L 74/49 (Erika; para. 75). A more lenient approach by the Commission can be found in the Decision of 9 July 2003, OJ 2004 L 31/1-20 (Natural disasters Italy until 1999, paras. 64-65). In this decision, concerning the damage after the wreck of the ship Erika, the Commission found France's method of assessing the damage acceptable since it was reasonable to use it to facilitate administration given the large area and the number of undertakings affected by the events.

41 Community guidelines for State aid in the agriculture and forestry sector 2007 to 2013 (2006/C 319/01), para. 123.

42 Ibid., para. 132(e).

43 Commission Decision of 14 July 2004, OJ 2005 L 74/49 (paras. 71-72).

44 Guidelines, para. 125(b).

45 See Commission Decision of 14 July 2004, OJ 2005 L 74/49, para. 35.

46 Commission Decision of 9 July 2003, OJ 2004 L 31/1-20 (Natural disasters Italy until 1999, para. 65): the loss was not assessed at the level of the individual company, which could lead to an inexact assessment of the actual damage, which in turn meant that there was a risk of overcompensation.
When assessing which damage represents a normal entrepreneurial risk, one might look at the extent of the damage: damage that is negligible in extent, as a rule, will not be eligible for aid. In the decision concerning the oil disaster with the ship Erika, the French government had even covered turnover losses of $2.7 \%$. The Commission considered that small-scale losses must be categorized as costs to be borne by undertakings in the normal course of their activity. Any economic activity is subject to a variety of greater and lesser risks (price fluctuation of production factors, fluctuation of the sales price of production, possible increase in charges, etc.) resulting from a variety of unforeseen circumstances. The Commission considers that when such risks lead to smallscale losses, they cannot give rise to an entitlement to compensation because that would mean that traders could claim compensation whenever they suffered the impact of any unforeseen event. ${ }^{43}$ In line with this general approach, the Commission considers that in the agriculture sector, losses must exceed a threshold of $30 \%$ (20\% in less-favoured areas) for aid to be deemed compatible with the common market under Article 107(2)(b) of the Treaty. ${ }^{44}$ The fact is that the Commission does not hesitate to assess the apparent 'abnormality' of the damage critically - the Commission has the last word in this matter, not the Member State.

\section{e. Prohibition of overcompensation}

The eligible aid should be proportionate to the damage suffered. In many decisions, the Commission tests primarily whether or not the Member State has overcompensated. The question is, however, whether the prohibition of overcompensation is a substantive criterion in assessing the compatibility of the aid granted with the internal market. One can also say that compensating damage in spite of the criteria mentioned above will lead automatically to overcompensation. The prohibition of overcompensation is hence linked intrinsically to the criteria discussed above. For example, the compensation of damage not linked directly to an exceptional occurrence might lead to overcompensation. ${ }^{45}$ The same thing can be said when the damage is apparently not assessed in an objective manner. ${ }^{46}$ The prohibition of overcompensation therefore does not simply mean that the Member State should not compensate more than the damage suffered. When aid is given for costs belonging to the normal entrepreneurial risks, to indirect 
damage, or to damage not assessed in an individual and objective manner, there is a real risk of overcompensation.

\section{Compensations Falling Within the Scope of Article 107(3)(c) TFEU}

Article 107(3)(c) is also important for the subject-matter of this article, since the Commission sometimes finds a measure compatible with the State aid rules, despite the fact that a natural disaster or an exceptional occurrence did not cause the damage. Adverse weather conditions (frost, hail, rain, or drought), for example, in general do not qualify as an exceptional occurrence, but when these conditions cause companies to suffer major damage, the Commission might approve of these contributions by applying Article 107(3)(c). When an aid measure cannot be approved under $107(2)(b)$, this does not mean necessarily that the aid is prohibited. The Commission will ex officio consider whether the aid granted might be allowed since another exception to the prohibition of State aid applies. ${ }^{47}$ One of those exceptions is laid down in Article 107(3)(c) TFEU. This article states that aid to facilitate the development of certain economic activities or of certain economic areas may be compatible with the internal market, where such aid does not affect trading conditions adversely to an extent contrary to the common interest. Whether the aid affects trading conditions adversely will largely be dependent on the policy of the Commission formulated in different guidelines. Since this policy is too extensive to discuss, I will mention an example that might illustrate how compensations might be compatible with the internal market under this paragraph. The example concerns the compensations given to undertakings for damage resulting from adverse weather conditions.

As noted, the Commission generally does not qualify adverse weather conditions such as frost, rain, drought, or hail, as natural disasters. When events such as these cause significant damage to the agricultural production or means of production, aid might be compatible with the State aid rules. For this to be the case, the Commission will fall back on the policy formulated in the Guidelines for State aid in the agriculture and forestry sector and the SME regulation. ${ }^{48} \mathrm{~A}$ study of these regulations indicates that the criteria that the Commission uses to test the compatibility of aid under Article 107(2) also apply under the third paragraph. The SME regulation, for example, states that the maximum amount of loss eligible for aid should be reduced by any amount received under insurance schemes (prohibition of accumulation) and by costs not incurred by the adverse climactic event (direct causal link). Furthermore, the calculation of loss must be made at the level of the individual holding (individual assessment). ${ }^{49}$ The SME regulation and the Community Guidelines also contain further, more specific conditions. In recent years, an important goal of EU policy in this field was to stimulate farmers as much as possible to arrange insurance for the damages caused by bad weather. As a result, from 1 January 2010, the compensation offered must be reduced by $50 \%$ unless given to farmers who have taken out insurance covering at least $50 \%$ of their average annual production or production-related income and the statistically most frequent climatic risks in the Member State or region concerned. ${ }^{50}$

\section{The Relation between Legally Obligatory Compensations and the Prohibition of State Aid}

\section{Mandatory Damages in Relation to Government Acts Are Compatible with the State Aid Rules}

Damages that Member States are obliged to pay will not qualify as State aid. This follows from the Asteris decision of the ECJ. This case began after technical errors had been included in a regulation, resulting in the non-payment of aid to which Greek tomato concentrate producers were entitled. The Greek judge

47 See, for example, Commission Decision of 20 October 2004, OJ 2005 L 100/46, paras. 39-41, Commission Decision of 13 June 2000, OJ 2005 L 263/17 e.v. (Transport of Irish cattle, paras. 102-104 (ex officio testing to Article 107 lid 3 sub c EG)) and Commission Decision of 9 July 2003, OJ 2004 L 31/1-20 (Natural disasters Italy, paras. 50-54).

48 Community Guidelines for State aid in the agriculture and forestry sector 2007 to 2013 (2006/c 319/01) OJ 2006 C 319/1; and Commission Regulation (EC) No 1857/2006 of 15 December 2006 on the application of Articles 87 and 88 of the Treaty to State aid to small and medium-sized enterprises active in the production of agricultural products and amending Regulation (EC) No 70/2001 OJ 2006 L 358/3-21.

49 Articles 10 and 11 of the SME Regulation. See also the Community guidelines for State aid in the agriculture and forestry sector 2007 to 2013 (2006/c 319/01), paras. 124 et seq.

50 Article 11 para. 8 SME Regulation and para. 125 sub e of the guidelines, mentioned in the previous footnote. 
posed a prejudicial question, asking whether the compensation of damage would be compatible with State aid rules and if such compensation should be notified to the Commission. The ECJ ruled that the prohibition of State aid laid down in the EEC Treaty 'covers all aid granted by a Member State or through State resources to undertakings (...) and therefore concerns State interventions which might have the effect of distorting the normal conditions of trade between Member States (...).' It follows, the Court continued: that State aid, that is to say measures of the public authorities favouring certain undertakings or certain products, is fundamentally different in its legal nature from damages which the competent national authorities may be ordered to pay to individuals in compensation for the damage they have caused to those individuals. ${ }^{51}$

In a recent decision, the GC confirmed the Asteris decision and made clear that this rule also applies when the compensation is granted because of a breach of the fundamental right to property. ${ }^{52}$ Although it is hard to disagree with this, it is doubtful whether a sharp demarcation between State aid and government compensation can always be made, as will be discussed in part IV.

To obtain a clear view of the relationship between compensation and State aid law, one should note the decisions the Commission has taken on this issue. In the Akzo Nobel case, the Commission specified the conditions that a compensation has to fulfil to be compatible with State aid rules. This decision is also important since the Commission made clear that the Asteris rule also applies when the State liability is grounded on no-fault liability. The aid measure in-

51 Joined cases 106 to 120/87, Asteris AE and others v. Hellenic Republic and European Economic Community [1988], ECR 5515, para. 23. See also C. Quigley, European State Aid Law (Hart Publishing 2009), p. 31

52 Case T-62/08, ThyssenKrupp Acciai Speciali Terni SpA v. European Commission [2010], OJ C 221/37. An application of the Asteris rule can also be found in Commission Decision 9 March 2010, OJ L 118/45, 2010 (Farm Dairy, para. 88). The judgment of the GC has been confirmed by the EC) (joined cases C-448/10 P - C-450/10 P, ThyssenKrupp Acciai Speciali Terni SpA (C-448/10 P), Cementir Italia Srl (C-449/10 P) and Nuova Terni Industrie Chimiche SpA (C-450/10 P) v Commission), n.y.r. Where the matter of the compensation is concerned, especially the Commission Decision and the GC judgment are of relevance.

53 Commission Decision 16 June 2004, on aid to Akzo Nobel, C(2004) 2026fin. See also Commission Decision 20 December 2006, on aid to car dismantling company Steenbergen, C(2006) 6608def. volved a 'subsidy' (that the Commission also referred to as a 'compensation') given to the chemical company Akzo Nobel because of the (lawful) repeal of an environmental permit for a chlorine plant. This repeal caused the plant to be moved to another city, diminishing risky transports of the highly dangerous chlorine. The Dutch government offered the plant compensation of $80 \%$ of the damage it suffered because of the forced displacement (divestments, moving, and housing costs), amounting to $€ 31.68$ million. The question arose as to whether such a large sum was compatible with State aid rules. The Commission concluded that the compensation was indeed compatible:

A compensation will normally not selectively benefit an individual undertaking, as long as the compensation only serves to compensate the damage caused by the government action, and where the compensation is the direct result of this action and is assessed on the basis of a general compensation regulation which is directly linked to the right to property, as protected by the constitution and as recognized by the national courts. ${ }^{53}$

This decision clearly exemplifies what the Court of Justice meant when stating that compensations differ fundamentally from State aid. When government is legally bound to pay compensation, it does not aim at 'favouring' an individual undertaking as opposed to its competitors. The only aim is to offer an apt remedy for a wrongness incurred on this undertaking, or to offer some kind of compensation in situations of extreme hardship. A legally obligatory compensation is therefore primarily compensatory in character. This does not mean, however, that compensation might not serve other goals. In Dutch environmental law, for example, the granting of compensation is sometimes motivated by the wish of the authorities to facilitate the acceptance of unwelcome and more stringent environmental policy. The pursuing of such side goals does not mean per se that State aid is granted. Still, it is important to realize that where such not strictly compensatory goals clearly influence the amount of the compensation, there might be a risk of granting State aid.

This leads us to an important indicator of the compensatory character of damages, namely the extent of the compensation. Liability rules generally warrant that the damaged individual is not better off after receiving compensation. An established legal rule is the principle of restitutio in integrum: damages 
serve to bring the damaged individual back to his situation prior to the damaging act, as if the latter had not occurred. When this principle is respected, the Commission will normally not qualify the aid measure as State aid. The Commission thus stated in its decision concerning the German Indemnification and Compensation Act, which allowed for companies to buy land at lowered prices, that this law did not constitute State aid:

(...) in so far as the measures represent only compensation for expropriation or intervention of equivalent effect by the State authorities, and the benefits awarded are equal to, or less than the financial loss caused by such State intervention. ${ }^{54}$

In cases of no-fault liability, only disproportionate damages should be compensated. The principle of equality before the public burdens - and likewise its German counterpart, the principle of Sonderop$\mathrm{fer}^{55}$ - does not rely on the principle of 'restitutio in integrum'. It is clear that this, in principle, guarantees that the damaged person will not be put in a better position than he or she was before the damaging act occurred.

\section{Comments on the Asteris Case Law}

The Asteris case law and Commission decisions, such as in the Akzo Nobel case, offer a solid base for judging whether a compensation is compatible with State aid rules. Yet, they do not completely align with each other and raise questions as to how they fit in with national liability systems.

A first important point is that the Asteris judg ment demands for a national court to have judged that a legal obligation to compensate exists. The $A k z o$ Nobel decision, on the other hand, states that any judicial involvement can be limited to the situation where a regulation is applied, as long as this regulation reflects a general legal principle that has been recognized by the national courts. The Commission thereby brings about an important nuance to the $A s$ teris decision. While it is true that in most Member States the national courts have the last word on this matter, one might wonder whether this is a limited perspective. In the Netherlands and in France, to name but two Member States, it is common for the national authorities to decide whether an obligation to compensate exists. This applies to claims concerning unlawful and lawful government actions. By de- manding that the individual who has suffered damages first addresses his or her claim to the competent authority, an amicable settlement might be arranged; furthermore, this procedure has the function of putting the case in order and getting all the facts straight before the judge is addressed. ${ }^{56}$ Only when the individual who has suffered damages is not satisfied with the 'damage decision' will he or she be able to contest this decision before the courts. This practice shows that it is not always necessary for a national court to intervene in government liability cases for a liability claim to succeed. Although the Asteris decision does not refer to this practice, it is in line with the rationale of this decision that compensations granted by national authorities are, in essence, an application of a general legal obligation to compensate damages, and are compatible with State aid rules. ${ }^{57}$

Second, the question arises whether the decision to compensate should, at all times, be based on a written regulation, as implied by the Akzo Nobel decision, which refers to a 'general compensation regulation'. Again, in most situations, the question as to whether a legal obligation to pay damages exists will involve the application of some kind of written regulation. In the end, State liability comes down to spending public funds, which as a rule requires some kind of legal basis. It is important to note, however, that a legal obligation to pay damages is sometimes based on unwritten law. In France and the Netherlands, nofault liability on the basis of the equality principle was developed by administrative courts, largely independent of any statute or other written source of law. The further development of the equality doctrine has been a mixed affair in both countries: sometimes, this principle is reflected in a regulation that applies to a specific situation. ${ }^{58}$ When a regulation is absent,

54 Commission Decision of 20 January 1999 on the acquisition of land under the German Indemnification and Compensation Act (notified under document number C(1999) 42).

55 This can be translated as an 'exceptional sacrifice' made in the general interest.

56 In Dutch law, this decision is called the administrative decision on paying damages (zelfstandig schadebesluit). French administrative law in liability cases also uses this concept: see on the 'décision préalable' J. Rivero \& J. Waline, Droit administratif, Paris: Dalloz 2006, p. 570 .

57 Implicitly, this can also be deduced from the Akzo Nobel decision, which concerned a legal obligation to pay damages, which was assessed by a national authority (the Ministry of Environmental Affairs).

58 For example, the French Code de l'urbanisme and its Dutch counterpart, the Wet op de ruimtelijke ordening. 
a legal obligation to compensate can still exist, in which case the party that has suffered damages will have to address the public authority and (optionally) the administrative or civil courts. Whether a regulation exists or not, in principle, does not make a difference as to when a legal obligation exists, since the same conditions apply. In conclusion, it is important to note that a legal obligation to compensate can exist, even in the absence of a statute.

Lastly, the Akzo Nobel decision raises the question of the interpretation of the provision according to which the compensation should be based on a compensation regulation 'which is directly linked to the right to property, as protected by the constitution'. Again, it is a question of whether or not this approach is too narrow. It is clear that this phrase covers situations of expropriation of land and comparable violations of property rights, such as the nationalization of companies. Furthermore, the German concept of a Sonderopfer has a strong link to the right to property, as protected by Article 14 of the German Constitution. Looking at other Member States, it is clear that a breach of the right to property cannot always explain compensation regulations. It can even be said that the concept of equality before public burdens owes its existence to the will of the legislature and/ or the national courts to offer more protection than the right to property can offer. In other words, even in the absence of a breach of the right to property, a legal obligation to compensate for damages can exist: the equality principle does not focus on the question whether the right to property is violated but on certain qualities of the damage, which have to be both special and abnormal. ${ }^{59}$

59 The fact that the liability regime based on violations of the right to property can and should be distinguished from the violation of the equality principle also follows from the FIAMM judgment of the ECJ. In this decision, the ECJ stipulated that Community law currently does not recognize the possibility of no-fault liability based on the breach of the right to equality. Only when the right of property is infringed upon, or when Community institutions have acted unlawfully, can the Community be held liable (Article 340 TFEU)

60 As stated, the Akzo Nobel decision might be considered as an application of the equality principle by the Dutch government. One can also take note of the Commission Decision of 8 December 1999 on the measure which the Netherlands intends to implement concerning rationalization of pig assembly centres (notified under document number C(1999) 5209) OJ $2000 \mathrm{~L}$ 144/28-34. In this decision, the Commission ruled that the Dutch authorities 'indirectly confirm that there is a legal obligation to make provision for transitional measures or compensation arrangements.' The aid measure was held compatible with the internal market.
So far, the EU courts have not ruled on the question whether decisions to compensate for damage under this regime are compatible with State aid, but it is highly likely that they would answer this question affirmatively. ${ }^{60}$ This would seem logical, since the equality principle is rooted in the law of several Member States. Furthermore, the threshold offered by the criteria of special and abnormal events is quite high, so that equality-based compensations can only be obtained normally by persons and companies that have suffered very grave and individual damage. By staying within the limits of this strict case law, the compensatory character of the damages is not in question and the Commission need not be notified of compensations given on this basis.

In conclusion, a damage compensation has to meet four conditions to be compatible with State aid rules. 1. The compensation has to be based on a general rule of law, be it in the form of a regulation that provides for a right to damage compensation, or as an unwritten principle of law, as recognized by national courts. The foundation of the right to compensation in law guarantees that every individual company can invoke this rule equally, so that it is indubitable that the compensation might provide for selective benefits for certain groups in society.

2. This general rule of law should be an expression of a legal obligation for damages. Among those rules are, in any case, the obligation to compensate after unlawful government action and the right to compensation in the case of violations of the right to property, which cover both the deprivation of property (cases of expropriation, for example) and the regulation of property (the revocation of a permit, for example); Article 1 of the First Protocol to the ECHR protects both situations. Lastly, compensations based on no-fault liability, which are generally based on the equality principle or comparable concepts (such as the German Sonderopfer) as a rule will also be compatible with State aid law. When compensating on these grounds, the compensatory character of the compensation is not debatable.

3. There has to be a clear and direct link between the damaging government act and the right to compensation. When this is not the case, there is a presumption that the government did not actually want to fulfil its legal obligations, but wanted to pursue other policy-related goals.

4. When granting compensation, the benefits awarded must be equal or inferior to the financial loss 
caused by such State interventions. At all times, overcompensation should be avoided. This is guaranteed sufficiently when the conditions mentioned under 1, 2, and 3 are respected. However, there is a danger of overcompensation when more damage is compensated than was suffered (through different sources of compensation, for example) or when compensation is given for damages that fall within the normal business risks.

\section{When Do Mandatory Damages Amount to Unlawful State Aid?}

In the previous paragraph, I aimed to give a rough outline of the conditions that damage compensations must fulfil to fall outside the scope of State aid law. When applying these basic rules, a discussion might arise, since vagueness surrounds the conditions mentioned. For example, when is a causal link sufficiently direct? How should the exact amount of damage be assessed? Which types of damage and costs belong to the 'normal risks inherent in trading'? A Dutch author once described the position of public authorities as a prisoner's dilemma: will they be in violation of the European Convention for Human Rights (by violating the fundamental right to property) or the TFEU (by granting too much compensation and breaching State aid law) $?^{61}$ Although it seems that public authorities in general know how to use their latitude in a legally responsible way, the risk of granting State aid is often present. In this paragraph, I will discuss situations in which questions such as these arose to illustrate how financial means that claim to be compensatory in character can qualify as State aid.

\section{Serving More Goals than Mere Compensation}

As stated, the compensatory character of damages is of fundamental importance for the question if they fall within the scope of the State aid rules. An important indicator therefore might be the question whether the damages aim at doing something more than merely offering compensation. It should be noted that the serving of policy goals is a common side effect of government compensations. For example, when combating a contagious disease among animals, it is of prime importance to trace the possi- ble sources of the disease as soon as possible. The high thresholds for liability in this field can hinder reaching this goal. In the case concerning Booker Aquaculture, the ECJ stressed that, in general, each individual must bear the damage he or she has suffered personally and that losses due to disease or suspected disease, in principle, are normal farming risks. ${ }^{62}$ A possible effect might be that producers are not tempted to slaughter their animals and will take the risk that meat from those calves enters the food chain untraced. When producers know that they will be compensated for combating measures that affect their livestock, they will be more willing to notify the public authorities that an outbreak has possibly taken place. This facilitates considerably the combating of contagious diseases. $^{63}$

The field of agriculture and the outbreak of contagious diseases have their own special rules that specify which costs and damages can be compensated. Public authorities, therefore, to a certain extent, can compensate to a higher degree than the boundaries set by the law concerning government liability. ${ }^{64}$ There are limits, however, to compensating specific groups of undertakings and purposely offering more than that required by law. The case concerning the common guidelines for the use of economic development funds by the Land of Berlin can illustrate this. The Land of Berlin was planning to carry out public measures (construction work, the release of land, and other urban planning and development measures) to correct the urban development that had arisen since the division of Berlin. The public measures, in some cases, could mean that businesses would have to be relocated or that substantial building alterations to their premises had to be made. The Guidelines' aim was to ensure that firms would not be forced by the public measures to close down their business in Ber-

61 Daalder, Het tweesnijdend zwaard van Vrouwe Justitia, Nederlands Tijdschrift voor Bestuursrecht 6/2006, p. 26

62 Joined Cases C-20/00 and C-64/00, Booker Aquaculture v. The Scottish Ministers [2001], p. I-7411. The ECJ stated that 'the petitioners (...) can expect, as farmers, that a fish disease may break out at any moment and cause them loss. Such risk is inherent in the business of raising and selling livestock and is the consequence of a natural occurrence, so far as both List I and II diseases are concerned' (para. 83).

63 See also the Opinion of AG Jacobs in Case C-428/99, H. van den Bor BV v. Voedselvoorzieningsin-en verkoopbureau [2001], para. 32.

64 See, in particular, the conditions mentioned in the Community guidelines for State aid in the agriculture and forestry sector 2007 to 2013 (2006/C 319/01), para. 16. 
lin or to leave the city. Therefore, all kinds of costs in a direct relation to the public measures were eligible under the scheme: costs of dismantling and setting up operating equipment and fixtures again, costs of preparing replacement premises, and costs incurred because previous operating equipment and/or fixtures could no longer be used. Under the common compensation regime in the Building Code, these costs could not be compensated. Germany claimed that the Guidelines thus had to fill the 'gap' in Germany's legal system, and that the payments merely filled in what was 'forgotten' by the Building Code by private law. The common guidelines supposedly did nothing more than place the affected Berlin firms on an equal footing with others not affected by the public measures.

The Commission focused on the compensatory character of the aid measure. It pointed out that federal legislation and private law already provided the compensation for damages following from lawful public measures. The Commission's view that an advantage was conferred on the firms concerned by the common guidelines was also strengthened by the fact that the common guidelines made the payment by the State conditional on the firms relocating within Berlin. The Commission concluded:

This makes it clear that the aim of the common guidelines is to confer an advantage on certain firms to which other firms are not entitled, even though they are all affected by the same measures. The real purpose of the common guidelines is thus not confined to merely compensating for a disadvantage. Instead, as a clear regional policy tool, their purpose is to keep firms in Berlin. ${ }^{65}$

According to the Commission, the Berlin Guidelines were incompatible with the internal market. The same line of argumentation can be recognized in the recent case of ThyssenKrupp. Again, the authorities stretched the existing rules on compensation so far that the courts could only conclude that Italy was in breach of the State aid rules. In this case, the Italian authorities offered compensation to the electricity companies that were nationalized in 1962 . This com-

65 Commission Decision of 24 June 2003 concerning the aid scheme 'Common guidelines for the use of economic development funds by the Land of Berlin' OJ 2004 L 43/88.

66 Case C-86/89, Italy v. Commission [1990] ECR I-3891, para. 18, and Case C-301/87, France v. Commission [1990] ECR-307, para. 50 .

67 Commission Decision of 20 November 2007, OJ 2008 L 144/37, para. 61. pensation consisted of the granting of a preferential tariff (the 'Terni tariff') for the supply of electricity for a limited period of time: from 1963 to 1992, Terni could obtain electricity against a tariff that was the same as the tariff of the self-producers. The compensation therefore was not the traditional compensation applied in expropriation cases (which would entail the loss of the market value of the assets of the nationalized companies), but concerned operating aid - aid intended to relieve an undertaking of the expenses that it would normally bear in its day-to-day management or its usual activities. It is settled case law that such aid, in principle, distorts competition to an extent contrary to the common interest in the sectors in which it is granted. ${ }^{66}$

When Italy adopted a new national energy plan in 1991, a law was adopted that extended the existing concessions to 2001. Under this law, the preferential tariff was extended to 2001 as well. This law did contain a clause that provided for the phasing out of this tariff between 2001 and 2007. The Commission was notified of this law, and it decided that parts of it contained unlawful State aid, but held that the compensation clause was compatible with the State aid rules. In 2005 , however, Italy decided to interrupt the phasing out of the tariff and to extend the preferential tariff to 2010. Italy stated that the extension was a necessary and compulsory compensation for the damage caused by the nationalization of 1962. At the same time, Italy claimed that the reasons behind the extension were political in nature: Italy feared that the disruption of the preferential tariff might disrupt competition between the Terni companies and comparable companies abroad, who, as Italy claimed, could profit by lower energy prices. Putting an end to the preferential tariff might lead to an outplacement of the activities of the self-producers outside of the European Union, causing a major industrial crisis and a large-scale loss of employment. ${ }^{67}$

As was the case in the Berlin Guidelines case, the Commission and the GC took notice of the Italian law governing the compensation regime in cases like this. In the original decision to nationalize the Terni Company, the national legislature chose a specific date for the expiry of the Terni tariff, without any other temporal indication in Decree No 1165/63. The applicant had not established that the parliamentary documents revealed a wish by the legislature to align the duration of application of the Terni tariff with that of the self-producers' hydroelectric concessions, in that the renewal of the latter was to entail automat- 
ic extension of that tariff (as Italy stated). This parallelism in treatment with those hydropower producers who had seen their concessions renewed, according to the Commission, lay 'at the heart of the compensatory mechanism. ${ }^{68}$ This parallel treatment, however, was foreseen in the expropriation arrangement only for 30 years, not indefinitely. The GC stated that there is no 'rule, principle of Community law, provision of national law or decision of a national court on which to base its interpretation, which would lead to the grant of compensation for an indefinite period or providing more generally for the possibility of taking account of events subsequent to the fixing of the compensation in order to alter the estimate of the nationalized or expropriated asset and, therefore, the scope of the compensation. ${ }^{169}$ According to the Commission, 'compensation for an expropriation cannot consist in an open-ended arrangement, but must be clearly and predictably established at the time of the expropriation, subject to the possibility for the expropriated company to challenge the proposed amount. ${ }^{70}$

These cases show that where authorities compensate willingly outside of the existing rules on compensation (as in the Berlin case) or stretch the existing compensation rules in a manner no longer in a sufficiently direct causal link to the government act that caused the damage (as in the Italian case), there is a risk of acting in violation of the State aid rules. Both cases also show that Member States should not expect that they dispose of a large margin of appreciation where the assessment of the extent of the damage is concerned. On the contrary, the GC opted for a very precise study of the original decision to nationalize the companies in order to determine the exact limits of the legal obligation to compensation. 'Labelling' a financial contribution as legally obliged compensation does not guarantee that it is compatible with State aid rules.

\section{Compensation of Normal Business Risks}

The risk of granting State aid under the guise of damage compensation might be even greater when the government liability is based on the principle of equality before the public burdens. When liability based on unlawfulness and liability for expropriations is concerned, amongst the Member States - and likewise in the case law of the ECJ and the ECtHR
- there is a broad consensus on the compensable damage and the situations in which liability might arise. Such consensus is far from present when the liability based on lawful acts is concerned. Many Member States do not recognize such a type of liability and where they do, there is a lack of clarity as to the question of when the conditions of 'specialty' and 'abnormality' are fulfilled. This lack of consensus was an important factor in the ECJ's decision not to recognize this type of liability under the wings of Article 340 TFEU. ${ }^{71}$

While a study of the case law in the Member States that do recognize this type of liability shows that the same (high) thresholds apply, it is also true that the conditions for liability without fault to exist are, to a certain extent, vague. This vagueness certainly surrounds the criterion of the 'normal risks inherent in business', which is more or less the same as the 'abnormality' criterion. Compensation for damages that result from these risks cannot be awarded, since a breach of the equality principle will not be established. However, since it is debatable which risks can be found 'normal', it is not always easy to delineate between awarding compensation and granting State aid. For example, the changing of the conditions under which a permit can be used, as a rule, will not lead to government liability. Changing the conditions generally belongs to normal societal or entrepreneurial risks. ${ }^{72}$ Dutch owners of cables and pipes, however, can claim compensation when the conditions of their permits are changed and their cables or pipes have to be displaced, depending on the number of years that the cables have lain un-

68 Commission Decision of 20 November 2007, OJ 2008 L 144/37, para. 92.

69 Case T-62/08, ThyssenKrupp Acciai Speciali Terni SpA v European Commission, OJ 2008 C-221/37, para. 131. See for a comment on this case M. Baart and M.K.G. Tjepkema, Administratiefrechtelijke Beslissingen, 2012, p. 27 and Dirk. T. Wiemer, Zeitschrift für Beihilfen- und Subventionsrecht, 2011, p. 25-39.

70 Commission Decision of 20 November 2007, OJ 2008 L 144/37, para. 74.

71 According to the EC), the convergence on the liability for unlawful acts existed 'in no way' regarding the possible existence of a principle of liability in the case of a lawful act or omission of the public authorities, in particular where it is of a legislative nature (Case C-120/06 P, FIAMM v. Council and Commission [2008], ECR I-6513, para. 175 (see also para. 170)).

72 See for French case law Conseil d'Etat 29 May 1985, Actualité Juridique Droit Administratif 1985, p. 510 (Société Trans.Union) and for a Dutch case ABRvS 28 January 2009, LJN BH1100 (Revocation Permit Cockle Fishery). 
derground. This compensation regulation ${ }^{73}$ was the result of a political compromise between the owners of the pipes and the Dutch government: by offering compensation, the authorities prevented a situation where the cable and pipe owners would start judicial proceedings whenever the Ministry of Waterways and Public Works embarked on projects that harmed their interests. The criterion of the normal business risks was simply set aside, even though there is no doubt that the displacement of cables and pipes falls within the business risks of the owners.

A Dutch case concerning the prohibition of a mechanical cockle fishery provides another example. In 2004, the Dutch government decided to stop giving permits for mechanical cockle fisheries in the Wadden Sea. This decision was prompted by more stringent European policy on the conservation of nature, which entailed that mechanical cockle fisheries would only be allowed if the fishery companies switched to a more sustainable way of fishing for cockles. In the short term, this aim was not feasible, so the Dutch government decided to allow for the manual fishing of cockles only, thereby ending the cockle fishery activities of several companies, who claimed that this decision cost them millions of Euros. The Dutch cabinet decided that compensation was due. After a study of the different legal grounds that applied in this case, the Dutch government saw it as a legal obligation to pay the cockle fishing companies €92 million.

The cockle fishery case did prompt a fierce debate in the Dutch literature on the question of whether the damage compensation was legally mandatory or whether the Dutch government (also) wanted to appease the cockle sector, which had fished in the

73 The Damage Compensation Regulation Displacement of Cables and Pipes within and outside of Waterways and Public Works (Nadeelcompensatieregeling Verleggen Kabels en Leidingen in en buiten rijkswaterstaatwerken 1999).

74 Germany stated that the payments under the common guidelines were designed for 'unforeseeable disadvantages'. The Commission noted, however, that damage caused by the termination, premature cancellation and discharge of a contract of use are risks inherent in business life and are thus foreseeable. It could therefore not accept Germany's argument.

75 Van der Wal \& Van Schayk, Financiële compensatie mechanische kokkelvisserij: politieke keuze én juridische noodzaak!, Overheid \& Aansprakelijkheid 2007/1, p. 2-8.

76 See especially Hoitink \& Backes, Financiele compensatie mechanische kokkelvisserij: politieke keuze of juridische noodzaak?, Overheid \& Aansprakelijkheid 2006/2, p. 24-30.

77 See e.g. ABRvS 27 April 2011, L J. N. BQ2653 (Hinderplaat 2007)
Wadden Sea for decades and now had to end its activities. The debate in the literature revolved mainly around the question of whether the cockle companies could have foreseen the decision to stop granting permits. It follows from Dutch damage compensation law that foreseeable damages in general do not have to be compensated at all or only partly; in the Berlin Guidelines case, the European Commission also mentioned this criterion. ${ }^{74}$ The rationale is that good entrepreneurship also means that companies prepare themselves for foreseeable damages, taking decisions to mitigate the damaging consequences.

Was it in anyway foreseeable that the government would no longer grant permits for mechanical cockle fisheries? Some authors claimed that in this case too, the decision was unforeseeable. For years, the cockle companies had been given permits, thus leading to the legitimate expectation that this would not stop suddenly. Furthermore, while it might have been foreseeable that cockle fisheries would be allowed under more stringent conditions, it could not be said that a total ban was foreseeable. Previous limitations on cockle fisheries were only temporary and not indefinite. ${ }^{75}$ Other authors argued that a total ban was foreseeable. ${ }^{76}$ Since 1981, the Wadden Sea had been designated as a natural monument, and since 1991, had been a special protection area based on the Birds Directive, which meant that all activities with significantly dangerous consequences for the natural values of the area concerned were, in principle, prohibited. Furthermore, in the surrounding countries (Denmark and Germany), a total ban on mechanical cockle fisheries had been imposed at the start of the 1990s, making it hard to believe that a total ban in the Wadden Sea could have come as a surprise. This also means that the expectation of obtaining a new permit under the same conditions could hardly be called legitimate: under the circumstances, the renewal of their permits had become more improbable over the years. Lastly, the Dutch case law on the compensation of individuals who are dependent on natural resources and who operate their businesses in an environment that is subjected to stringent government regulations - largely dictated by EC policy and legislation - is very strict. ${ }^{77} \mathrm{~A}$ reasonable and careful entrepreneur has to take into account that decisions, even very stringent ones, can be taken when they operate within an environment that is vulnerable. It was not up for debate that the mechanical cockle fishery was under strict European supervision. It is conceivable that in the light of the Habitats Direc- 
tive, the permits could have been refused in a much earlier stage. $^{78}$

The Commission was not notified of the lump sum granted by the Dutch government, so it is not known whether the Dutch government acted in violation of the State aid rules. If the Commission had judged that this was the case, this would have meant that the aid, including interest, would have had to be recovered from the cockle companies.

\section{Concluding Remarks}

The relationship between damages and State aid is a complex one. At first glance, although the granting of damages would seem to be unproblematic in light of the State aid rules, Commission decisions, union case law, and national practice have shown that public authorities provide regularly for financial contributions to firms where it is uncertain that the State aid rules have been respected. Authorities should be aware of the fact that the Commission and the Courts have opted for a restrictive approach to when deciding which causes qualify as a natural disaster or an exceptional occurrence. Furthermore, they tend to opt for a precise test of the relevant criteria (sufficiently direct causal link, individual and objective assess- ment of damages, prohibition of overcompensation and accumulation). This precise way of testing is also recognizable where - other than the exceptions mentioned in Articles 107(2)(b) and 107(3)(c) - the State can be held liable in court for damages, as paragraph V showed.

This does not mean necessarily that authorities cannot make special damage regulations for specific groups of undertakings (which suffer from infrastructural works, for example). Public authorities should be careful, however, to provide for the compensation of damages that fall usually within the normal business risks, in order to bind undertakings to a certain region. Meanwhile, this strict testing of damages to the State aid rules can lead to harsh results for the recipients of the aid. Not only have they been confronted with acts which severely harmed their interest. When the compensation is qualified as unlawful State aid, the same government that thought it owed parties a compensation will have to retrieve the aid. This is another reason why the public authorities should be careful in making 'instrumental' use of compensation mechanisms.

78 Hotink \& Backes 2006 